\title{
HONFOGLALÓK SZÁRMAZÁSÁNAK ÉS ROKONSÁGI VISZONYAINAK VIZSGÁLATA ARCHAEOGENETIKAI MÓDSZEREKKEL
}

\author{
Neparáczki Endre \\ Szegedi Tudományegyetem, Genetikai Tanszék, Szeged \\ Témavezetők: Dr. Török Tibor és Dr. Pálfi György
}

Neparaczki E.: Archeogenetic analysis of the origin and genetic relations of the Hungarian conquerors. In the last few decades genetic analysis has been playing an increasing role in tracing the origin and relation of human populations. DNA sequences isolated from ancient human remains can be used, to unravel ancestor-descendant relationships between populations and reconstruct population history.

In our research we successfully optimized ancient DNA extraction methods and adapted the latest haplotyping methods. We complemented the traditional PCR based HVR sequencing method with the SNaPshot assay, which is used to determine 22 haplotype defining SNP-s in the mtDNA coding region. In the case of bone samples with best DNA preservation the same method could also be used to determine the paternal (Y chromosome) haplogroup.

In the last few years the next generation sequencing method (NGS) has revolutionized the aDNA field, by providing reliable high quality sequence reads, and enabling to sequence even whole ancient genomes. Recently we have adapted the NGS method in our lab (Archoegenetic Laboratory, University of Szeged) and sequenced whole mtDNA genomes from a large number of Hungarian conqueror samples. Some $40 \%$ of the conquerors had East-Central Asian origin, other $60 \%$ of the samples had best matches with modern people from Europe.

Keywords: Ancient DNA; Hungarian Conquerors; Next Generation Sequencing; DNA Sequence Analysis.

\section{Kutatási előzmények}

A népcsoportok rokonsági és leszármazási viszonyainak vizsgálatában az utóbbi évtizedekben egyre nagyobb szerepet játszanak a genetikai vizsgálatok, amelyek kezdetben ma élő emberekre korlátozódtak. A mai adatokból azonban csak közvetett módon következtethetünk az egykori őseinkre. Ezzel szemben a közelmúltban megjelent új tudományág, a régészeti genetika vagy archeogenetika közvetlen adatokkal szolgál, vagy bármely ősi népesség, például a honfoglalók származásáról, rokonsági viszonyairól.

A hazai régészeti genetikai kutatások 2000-ben kezdődtek a Szegedi Biológiai Központban, Raskó István kutatócsoportjában. Itthon nekik sikerült először ásatag DNS-t izolálniuk, és mtDNS haplotipizálási módszert kidolgozniuk (Tömöry és mtsai 2007). Vizsgálták a kunok eredetét, a magyar nyelvü populációk és a honfoglalók lehetséges genetikai kapcsolatait és néhány honfoglaló mintán Y-kromoszómás vizsgálatot (Tat) is végeztek (Csányi és mtsai 2008).

Munkánk során sikerrel optimalizáltuk az ásatag DNS izolálásának módszerét, és adaptáltuk a legújabb haplotipizálási módszereket. Rutinra tettünk szert az ásatag csontokból izolált mitokondriális DNS haplotípusának meghatározásában, amelynek 
során a szokásos HVR szakaszok szekvenálását kiegészítettük a kódoló szakaszok SNP haplotípus meghatározásával a SNaPshot technika alkalmazásával (Salas és mtsai 2005). Ugyanezen módszerrel a jobb megtartású csontokból, meg tudtuk határozni az apai ág (Y kromoszóma) haplocsoportját is (Neparáczki és mtsai 2016).

Az archeogenetikai kutatások területét az utóbbi néhány évben forradalmasította az újgenerációs szekvenálás (NGS) módszer alkalmazása (Templeton és mtsai 2013). A laborunkban az elmúlt években elsajátítottuk az NGS könyvtár készítés módszerét (Neparáczki és mtsai 2017). A beállított módszerekkel célul tűztük ki a honfoglaláskori minták nagyfelbontású genetikai vizsgálatának elvégzését egy kellöen reprezentatív mintaszámon. Célunk volt néhány temető teljes anyagának vizsgálata, amely összehasonlítási alapul szolgálhat a további temetőkből és korszakokból később elvégzendő vizsgálatok számára, továbbá felderíthetők a temetőn belüli és temetők közötti rokonsági viszonyok is.

\section{Alkalmazott módszerek}

$\mathrm{Az}$ archeogenetikai vizsgálatokhoz kiválasztott leletekből a tömör csontokból, foggyökérből és sziklacsontokból vettünk mintát. Ezekből csontport kellet készíteni; munkánk kezdeti szakaszában adaptáltunk egy kéziszerszámmal müködő speciális csontporítási eljárást (Benoit és mtsai 2013), majd újabban áttértünk a malmos csontporításra.

Az ásatag DNS extrakció során több módszert is kidolgoztunk és összehasonlítottunk, ezzel az ásatag DNS kivonás metodikáját optimalizálva (Rohland és Hofreiter 2007). A munkánk első felében PCR amplifikálás után Sanger szekvenálással határoztuk meg a mitokondrium genom hipervariábilis régiójának szekvencia sorrendjét. Ezt a SNaPshot assay alkalmazásával egészítettük ki, amivel a kódoló régióban található, fontosabb SNPéket is meghatároztuk. Ezt a módszert Y kromoszomás markerek meghatározására is sikeresen adaptáltuk. A rokonsági kapcsolatok eldöntésére STR analízist végeztünk.

A disszertáció második felében az új generációs szekvenálás módszertanára tértünk át. Ehhez az ásatag DNS kivonatokból könyvtárakat készítettünk, amelyekből a minket érdeklő genom részleteket dúsítás után szekvenáltuk meg. Az így kapott mitokondrium genomok (anyai vonalak) földrajzi származási helyét filogenetikával határoztuk meg.

\section{Vizsgálati eredmények és következtetések}

Első kísérleteinkben a Karos-III. temető 19 sírjának 17 leletéből tudtunk sikeresen mtDNS-t kivonni, és meghatározni az egyének anyai haplotípusát, a teljes HVR-I és a részleges HVR-II szakasz szekvenálásával, illetve a kódoló régió 22 SNP pontjának a meghatározásával (Neparáczki és mtsai 2016). A 17 minta 7 fő haplocsoportba és 13 haplotípusba volt sorolható.

Haplocsoport megoszlása alapján ezen karosi populáció ősi európai és ősi ázsiai eredetü populációk keveredéséből származhatott. A populációgenetikai eredmények arra utaltak, hogy ez a keveredés valószínüleg i.e. 2000-700 táján, a bronzkor végén történhetett az Andronovo kultúra területén (mai Kazahsztán), mert a vizsgált populáció az innen származó ôsi populációkkal és ma itt található modern populációkkal mutatta a leghasonlóbb haplocsoport megoszlást. A haplotípusok egy része arra utalt, hogy a karosi honfoglalók ősei innen nyugat felé vándorolva további európai genetikai elemekkel keveredtek. Fontos hangsúlyozni, hogy a karosi populáció egy része biztosan nem 
származhatott Ázsiából, mivel a bennük kimutatott X2f és a H5 mitokondriális haplocsoportok valamint az I2a és R1b1b Y haplocsoportok szinte teljesen hiányoznak erről a területről. Adataink alapján a karosiak végső összetétele valahol a kelet-európai sztyeppén alakulhatott ki, és az X2f, H5 haplocsoportok elterjedtsége, valamint a T1a és J haplocsoportok gyakorisági adatai alapján arra következtettünk, hogy az ázsiai eredetü populációkkal keveredő népességek egy része a Kaukázus vidékéről származhatott.

Kísérleteink második felében már dúsítással kombinált újgenerációs szekvenálással dolgoztunk, és ennek eredményeképp a Karos-I temetőből 11, a Karos-II temetőből 44, a Karos-III temetőből 18, a Sárrétudvari-Hízóföld temetőből 6, a Kenézlö-Fazekaszug-II temetőből 4, a Szegvár-Oromdülö temetőből 2 és a Magyarhomoróg, OrosházaGörbicstanya, Szabadkígyós-Pálliget, Harta-Freifelt temetőkből 1-1 minta mtDNS genom szekvenciáját határoztuk meg. Ez a 89 minta tehát 3 temető csaknem teljes anyagát tartalmazza, ami nagyon reprezentatív mintaszámot jelent, a többi temetőből származó néhány minta eredményéböl pedig arra tudunk következtetni, hogy azok mennyiben hasonlítanak, vagy térnek el a karosi eredményektől. Ezen nagy mintaszámú nagyfelbontású adatok alapján már nagy biztonsággal körvonalazható a honfoglalók származása.

Azonos mitokondrium genommal rendelkeznek, vagyis anyai ágon testvérek vagy unokatestvérek lehetnek a következő egyének: Karos-I/1-Karos-I/2, a Karos-I/3-KarosI/5, a Karos-I/10-Karos-I/38, a Karos-II/9-Karos-II/60-Kenézlő-Fazekaszug-II/1027Kenézlő-Fazekaszug-II/1045, a Karos-II/16-Karos-II/54, a Karos-II/21-Karos-II/22, a Karos-II/31-Szabadkígyós-Pálliget/7/anc4, a Karos-II/52-Karos-III/11 (vezérek), a Karos-III/5-Karos-III/6, a Karos-III/7-Karos-III/8-Karos-III/9, a Karos-III/18-KarosIII/19. Ezek a rokonsági viszonyok arra utalnak, hogy a 3 karosi temető népessége egymástól markánsan elkülönül, az egyes temetőkön belül vannak rokonok, de temetők között csak a vezérek testvérek. Meglepő módon azonban a többi temetőkböl vett kis mintaszám ellenére is több valószínü közvetlen rokont találtunk az egyes karosi egyének és egyéb temetőkből származó egyének között. A temetők közötti rokonok hiánya, valamint a markánsan eltérő haplocsoport összetétel arra utal, hogy Karoson 3 hasonló összetételü, de eltérő azonosságtudatú törzs telepedett le. Ha ehhez hozzávesszük, hogy a távoli temetők között viszont az azonos mtDNS genomok alapján közvetlen rokonok valószínűsíthetők, az a következtetés adódik, hogy a Kárpát-medence elfoglalását követően az egyes törzseket megosztották, tagjaikat széttelepítették, és az egyes területekre különböző törzsek töredékeit telepíthették egymás mellé.

\section{Összegzés}

Kísérleteinket a nemzetközi követelménynek megfelelö ásatag DNS laborban végeztük az archaikus DNS izolálás és szekvencia analízis legmodernebb módszereivel. Ez kezdetben az mtDNS HVR régió szekvenálásával, és 22 mtDNS kódoló régióban elhelyezkedő SNP vizsgálatával (GenoCoRe22) történt, amely munkánk kezdetekor a legjobb módszernek számított. A PCR alapú módszerrel az Y kromoszóma esetében kizárólag azt a 25 SNP-t vizsgáltunk (GenoY25), amelyek a főcsoport besorolásához szükségesek. Ezt a metodikát Magyarországon először nekünk sikerült alkalmazni, ez a ún. klasszikus módszer legfejlettebb változata az archeogenetika területén.

A továbbiakban is igyekeztünk lépést tartani a szakterület élvonalával, ezért áttértünk a dúsítással kombinált újgenerációs szekvenálásra. Első NGS munkáinkban újravizsgáltunk korábbi mintákat, és demonstráltuk a klasszikus és NGS módszer 
minősége közti különbséget. Kimutattuk, hogy az új generációs szekvenálással kapott eredmények tökéletesen megbízhatók, míg a PCR alapú haplotípus eredmények meglehetősen megbízhatatlanok.

További NGS szekvenálásokkal kibővítettük a honfoglaló leletekböl készített teljes mitokondrium genom gyüjteményünket reprezentatív mennyiségüre $(n=89)$. Ezt követően minden egyes lelet filogenetikai leszármazását meghatároztuk, amiből azt kaptuk, hogy a honfoglalók anyai ágon nagyrészt két különbözö, jól körvonalazható földrajzi területröl származtak: Kelet-Âzsiából és Észak-Nyugat-Európából, továbbá egy kis részük a Kaukázus régióból és Közel-Keletröl.

\section{Felhasznált irodalom}

Benoit, J-N., Quatrehomme, G., Carle, G., Pognonec, P. (2013): An alternative procedure for extraction of DNA from ancient and weathered bone fragments. Medine, Science and the Law, 53: 100-106. DOI: $10.1258 / \mathrm{msl} .2012 .012026$

Csányi, B., Bogácsi-Szabo, E., Tömöry, G., Czibula, Á., Priskin, K., Csősz, A., Mende, B., Langó, P., Csete, K., Zsolnai, A., Conant, E.K., Downes, C.S., Raskó, I. (2008): Y-chromosome analysis of ancient Hungarian and two modern Hungarian-speaking populations from the Carpathian Basin. Annals of Human Genetics, 72: 519-534. DOI: 10.1111/j.14691809.2008.00440.x

Neparáczki, E., Juhász, Z., Pamjav, H., Fehér, T., Csányi, B., Zink, A., Maixner, F., Pálfi, Gy., Molnár, E., Pap, I., Kustár, Á., Révész, L., Raskó, I., Török, T. (2016): Genetic structure of the early Hungarian conquerors inferred from mtDNA haplotypes and Y-chromosome haplogroups in a small cemetery. Molecular Genetics and Genomics, 292(1): 201-214. DOI: $\underline{10.1007 / \mathrm{s} 00438-016-1267-\mathrm{z}}$

Neparáczki, E., Kocsy, K., Tóth, G.E., Maróti, Z., Kalmár, T., Bihari, P., Nagy, I., Pálfi, Gy., Molnár, E., Raskó, I., Török, T. (2017): Revising mtDNA haplotypes of the ancient Hungarian conquerors with next generation sequencing. PLoS One, 12: e0174886. DOI: 10.1371/journal.pone.0174886

Rohland, N., Hofreiter, M. (2007): Ancient DNA extraction from bones and teeth. Nature Protocols, 2: 1756-1762. DOI: 10.1038/nprot.2007.247

Salas, A., Quintáns, B., Álvarez-Iglesias, V. (2005): SNaPshot Typing of Mitochondrial DNA Coding Region Variants. In: Goodwin, W. (Ed.) Forensic DNA Typing Protocols. Springer, Jena. pp. 197-208.

Templeton, J.E.L., Brotherton, P.M., Llamas, B., Soubrier, J., Haak, W., Cooper, A., Austin, J.J. (2013): DNA capture and next-generation sequencing can recover whole mitochondrial genomes from highly degraded samples for human identification. Investigative Genetics, 4: 26-29. DOI: 10.1186/2041-2223-4-26

Tömöry, G., Csányi, B., Bogácsi-Szabó, E., Kalmár, T., Czibula, Á., Csősz, A., Priskin, K., Mende, B., Langó, P., Downes, C.S., Raskó, I. (2007): Comparison of maternal lineage and biogeographic analyses of ancient and modern Hungarian populations. American Journal of Physical Anthropology, 134: 354-368. DOI: 10.1002/ajpa.20677

\section{A doktori értekezéshez kapcsolódó, referált, impakt faktorral rendelkező folyóiratokban megjelent szakcikkek}

Neparáczki, E., Kocsy, K., Tóth, G.E., Maróti, Z., Kalmár, T., Bihari, P., Nagy, I., Pálfi, Gy., Molnár, E., Raskó, I., Török, T. (2017): Revising mtDNA haplotypes of the ancient Hungarian conquerors with next generation sequencing. PLoS One, 12(4): e0174886. DOI: 10.1371/journal.pone.0174886. 2017 
Neparáczki, E., Juhász, Z., Pamjav, H., Fehér, T., Csányi, B., Zink, A., Maixner, F., Pálfi, Gy., Molnár, E., Pap, I., Kustár, Á., Révész, L., Raskó, I., Török, T. (2017): Genetic structure of the early Hungarian conquerors inferred from mtDNA haplotypes and Y-chromosome haplogroups in a small cemetery. Molecular Genetics and Genomics, 292(1): 201-214. DOI: $\underline{10.1007 / \mathrm{s} 00438-016-1267-\mathrm{z}}$

Levelezési cím: $\quad$ Neparáczki Endre

Mailing address: $\quad$ Szegedi Tudományegyetem, Természettudományi és Informatikai Kar Genetikai Tanszék

Közép fasor 52.

H-6726 Szeged

Hungary

endre.neparaczki@gmail.com 
